\title{
Pengaruh Media Peta Konsep Terhadap Hasil Belajar Peserta Didik Pada Sub Konsep Sistem Indera
}

\author{
Wina Nurlina ${ }^{1)}$, Purwati K Suprapto ${ }^{2)}$, Mufti Ali ${ }^{3)}$ \\ ${ }^{1}$ Pendidikan Biologi, Fakultas Keguruan dan Ilmu Pendidikan, Universitas Siliwangi \\ email: winalina0597@gmail.com@abc.ac.id \\ ${ }^{2}$ Pendidikan Biologi, Fakultas Keguruan dan Ilmu Pendidikan, Universitas Siliwangi \\ ${ }^{3}$ Pendidikan Biologi, Fakultas Keguruan dan Ilmu Pendidikan, Universitas Siliwangi
}

APA Citation: Nurlina, Wina., Suprapto, Purwati. K., \& Ali, Mufti. (2020). Pengaruh Media Peta Konsep Terhadap Hasil Belajar Peserta Didik Pada Sub Konsep Sistem Indera. Quagga: Jurnal Pendidikan dan Biologi, 13(1), 42-47. doi: 10.25134/quagga.v13i1.3213.

Received: 22-07-2020

Accepted: 16-11-2020

Published: 01-01-2021

\begin{abstract}
Abstrak: Penelitian ini bertujuan untuk mengetahui pengaruh media peta konsep terhadap hasil belajar peserta didik pada sub konsep sistem indera di kelas XI IPA di salah satu Sekolah Menengah Atas di Tasikmalaya yang proses pembelajarannya belum menggunakan media pembelajaran yang variatif.. Metode penelitian adalah quasi eksperimen dengan desain penelitian nonequivalent control group design. Populasi penelitian yaitu seluruh Kelas XI IPA sebanyak 7 kelas yang berjumlah 248 orang. Teknik pengambilan sampel menggunakan teknik purposive sampling. Sampel penelitian yaitu Kelas XI IPA 1 dan kelas XI IPA 2 yang dipilih berdasarkan pada kesamaan nilai rata-rata akhir semester dan kelas dengan nilai terendah. Instrumen penelitian terdiri atas soal kognitif pilihan ganda sebanyak 30 soal yang telah diuji validitas dan reliabilitas. Hasil analisis statistik didapatkan skor rata-rata $N$-gain kelas eksperimen 0,58 dan skor rata-rata $N$-gain kelas kontrol 0,38. Skor $N$ gain kedua kelas tersebut termasuk kategori sedang. Hasil uji hipotesis menggunakan uji t dengan taraf 5\% diperoleh thitung 6,5007 dan ttabel 1,9944. Dengan analisis thitung > ttabel maka HO ditolak dan Ha diterima. Dengan demikian dapat disimpulkan bahwa terdapat pengaruh media peta konsep terhadap hasil belajar peserta didik pada sub konsep sistem indera.
\end{abstract}

Kata kunci: Peta Konsep, Hasil Belajar, Sistem Indera

Abstrack: This study aims to determine the effect of concept map media on student learning outcomes in the sub-concept of the sensory system in class XI Natural Science in one of the High Schools in Tasikmalaya whose learning process has not used varied learning media. The method used is a quasi-experimental with the research design nonequivalent control group design. The study population was all Class XI Natural Sciences with 7 classes totaling 248 people. The sampling technique was using purposive sampling technique. The research samples were Class XI Natural Science 1 and Class XI Natural Science 2 which were selected based on the similarity of the average score at the end of the semester and the class with the lowest score. The research instrument consisted of 30 multiple choice cognitive questions that had been tested for validity and reliability. The results of statistical analysis showed that the experimental class $N$-gain average score was 0,58 and the control class $N$-gain average score was 0,38. The $N$-gain scores of the two classes are in the moderate category. The results of hypothesis testing using the t test with a level of 5\% obtained thitung 6,5007 and ttabel 1,9944. By analyzing thitung $>$ ttabel then $\mathrm{HO}$ is rejected and Ha is accepted. This it can be concluded that there is an effect of concept map media on student learning outcomes in the sensory system sub-concept.

Keywords: Concept Map, Learning Outcomes, Sense system

\section{PENDAHULUAN}

Pendidikan salah satu aspek penting bagi perkembangan sumber daya manusia, sebab pendidikan merupakan salah satu cara yang digunakan untuk meningkatkan kualitas diri manusia. Dalam dunia pendidikan, salah satu permasalahan yang sering kita jumpai adalah nilai rata-rata hasil belajar peserta didik masih dibawah Kriteria Ketuntasan Minimal (KKM).
Ada beberapa hal yang menyebabkan rendahnya hasil belajar peserta didik diantaranya belum memanfaatkan media pembelajaran yang variatif dan faktor dari dalam diri peserta didik itu sendiri seperti kurangnya semangat belajar.

Aktivitas peserta didik dalam kegiatan belajar lebih banyak mendengarkan informasi, mencatat materi yang dituliskan guru di papan 
tulis (Labibah, Raisyah, 2017:20). Dalam proses pembelajaran yang dilakukan seharusnya menggunakan media pembelajaran yang dapat meningkatkan semangat peserta didik untuk belajar dan diberikan kesempatan untuk berpartisipasi aktif sehingga peserta didik diharapkan dapat lebih memahami materi yang sedang dipelajari. Salah satunya pada mata pelajaran Biologi.

Berdasarkan hasil observasi di salah satu SMA Negeri di Tasikmalaya pada tanggal 03 Desember 2019, dengan peserta didik kelas XII IPA tahun akademik 2019/2020 diperoleh permasalahan bahwa peserta didik kurang memahami sub konsep sistem indera karena cakupan materinya cukup banyak, selain itu pada proses pembelajaran belum menggunakan media pembelajaran yang variatif sehingga peserta didik cenderung merasa jenuh saat pembelajaran berlangsung. $\mathrm{Hal}$ tersebut berpengaruh terhadap hasil belajar peserta didik. Pada tahun akademik 2018/2019 nilai rata-rata ulangan harian pada sub konsep sistem indera adalah 70, sedangkan KKM yang harus dicapai yaitu 76 .

Oleh karena itu, perlu dicari solusi untuk mengatasi permasalahan tersebut, diantaranya dengan menggunakan media pembelajaran yang sesuai dengan sub konsep sistem indera. Menurut Arsyad, Azhar (2010:5) menyatakan "Media dapat mewakili apa yang kurang mampu guru ucapkan melalui kata-kata atau kalimat tertentu. Ketidakjelasan bahan materi yang disampaikan dapat dibantu dengan media sebagai perantara". Kerumitan bahan ajar yang akan disampaikan kepada peserta didik dapat disederhanakan dengan bantuan media. Pemanfaatan media bisa dimaksimalkan dalam pembelajaran, menurut Marisa (2016:7-9) menyatakan bahwa "Manfaat media dalam kegiatan pembelajaran yaitu pembelajaran menjadi lebih menarik, interaktif, konkret dan nyata,serta dapat mendorong peserta didik belajar secara lebih mandiri". Ada beberapa media pembelajaran yang dapat diterapkan dalam penyampaian materi sistem indera diantaranya dengan menggunakan media peta konsep.

Menurut Novak, Joseph D dan Gowin, D Bob (1984:15-40) menyatakan bahwa "Peta konsep merupakan alat skematis untuk menyajikan hubungan yang bermakna antara konsep-konsep dalam bentuk proposisi. Peta konsep dimaksudkan untuk membantu peserta didik dalam belajar bermakna, membantu peserta didik untuk mengidentifikasi hubungan di antara konsepkonsep dan memberikan cara untuk memvisualisasikan konsep dan hubungan hierarkis". Adapun menurut Dahar, Ratna Wilis (2006:110) menyatakan bahwa, "Peta konsep dikembangkan untuk menggali struktur kognitif peserta didik dan mengetahui baik bagi peserta didik maupun guru mengenai apa yang telah diketahui peserta didik".

Menurut Vanides (2005: 28) menyatakan bahwa, "peta konsep merupakan representasi hubungan antara satu konsep dengan konsep lainnya. Peta ini dapat membangkitkan ide-ide orisinal dan memicu ingatan dengan mudah. Pembelajaran menggunakan peta konsep ini diharapkan dapat membantu siswa dalam memahami atau mengaitkan konsep-konsep dalam suatu materi yang dipelajari, sehingga dapat meningkatkan hasil belajar siswa".

Berdasarkan uraian diatas, rumusan masalah yang muncul yaitu apakah terdapat pengaruh media peta konsep terhadap hasil belajar peserta didik pada sub konsep sistem indera di Kelas XI IPA di salah satu SMA Negeri di Tasikmalaya?. Penelitian ini bertujuan untuk melihat apakah terdapat pengaruh media peta konsep terhadap hasil belajar peserta didik pada sub konsep sistem indera.

\section{METODOLOGI PENELITIAN}

Metode penelitian yang digunakan yaitu metode quasi experiment dengan desain penelitian nonequivalent control group design. Adapun desain nonequivalent control group design menurut Sugiyono (2017:169) sebagai berikut:

Keterangan

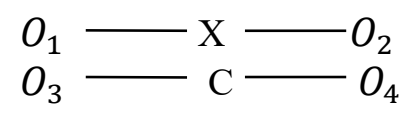

$O_{1}$ : Pengukuran awal (Pre test) kelas eksperimen

$\mathrm{O}_{2}$ : Pengukuran akhir (Post test) kelas eksperimen

$\mathrm{X} \quad$ : Perlakuan (treatment) dengan menggunakan media peta konsep

$\mathrm{O}_{3}$ : Pengukuran awal (Pre test) kelas kontrol

$\mathrm{O}_{4}$ : Pengukuran akhir (Post test) kelas kontrol

C : Kontrol 
Penelitian ini dilakukan di Kelas XI IPA di salah satu SMA Negeri di daerah Tasikmalaya yang proses pembelajarannya belum menggunakan media pembelajaran yang variatif dan dilaksanakan secara daring. Populasi dalam penelitian ini adalah seluruh kelas XI IPA tahun akademik 2019/2020 terdiri dari 7 kelas sebanyak 248 peserta didik. Pemilihan sampel dalam penelitian ini menggunakan teknik Purposive sampling. Kelas yang dijadikan sampel penelitian yaitu kelas XI IPA 1 dan kelas XI IPA 2 yang diambil berdasarkan kesamaan nilai rata-rata hasil belajarnya dan kelas dengan nilai terendah.

Instrumen penelitian terdiri atas soal kognitif pilihan ganda sebanyak 30 soal yang telah diuji validitas dan reliabilitas. Teknik Teknik pengolahan data menggunakan nilai gain yang dinormalisasi (N-gain) antara kelompok ekperimen dan kelompok kontrol. Adapun kriteria nilai Ngain menurut Hake (Meltzer, 2002:1261) sebagai berikut:

Tabel 1. Kriteria nilai N-gain

\begin{tabular}{|l|l|}
\hline Perolehan N-gain & Keterangan \\
\hline $\mathrm{N}$-gain $\geq 0,70$ & $\mathrm{~N}$-gain tinggi \\
\hline $0,30 \leq \mathrm{N}$-gain $<0,70$ & $\mathrm{~N}$-gain sedang \\
\hline $\mathrm{N}$-gain $<0,30$ & $\mathrm{~N}$-gain rendah \\
\hline
\end{tabular}

Sumber: Meltzer (2002:1261)

Uji prasyarat terdiri dari uji normalitas dan homogenitas. Uji normalitas yang digunakan adalah Chi Kuadrat sedangkan uji homogenitas yang digunakan adalah Fmaksimum. Untuk uji hipotesis menggunakan uji t.

\section{HASIL DAN PEMBAHASAN}

Berdasarkan hasil penelitian yang didapatkan, dilakukan uji hipotesis dengan uji t diperoleh $t_{\text {hitung }} 6,5007$ dan $t_{\text {tabel }} 1,9944$. Dengan analisis $t_{\text {hitung }}>t_{\text {tabel }}$ sehingga kesimpulan analisisnya tolak $H_{0}$ yang artinya terdapat pengaruh media peta konsep terhadap hasil belajar peserta didik pada sub konsep sistem indera.Hal tersebut bisa dilihat dari skor rata-rata pretest peserta didik pada kelas eksperimen sebesar 16,00, skor posttest sebesar 23,72 dan skor $\mathrm{N}$-gain sebesar 0,58. Sedangkan skor rata-rata pretest peserta didik pada kelas kontrol 15,5, skor posttest sbesar
20,72 dan skor $N$-gain sebesar 0,38. Berikut diagram perbandingan skor rata-rata pretest, posttest dan $\mathrm{N}$-gain kelas eksperimen dan kelas kontrol.

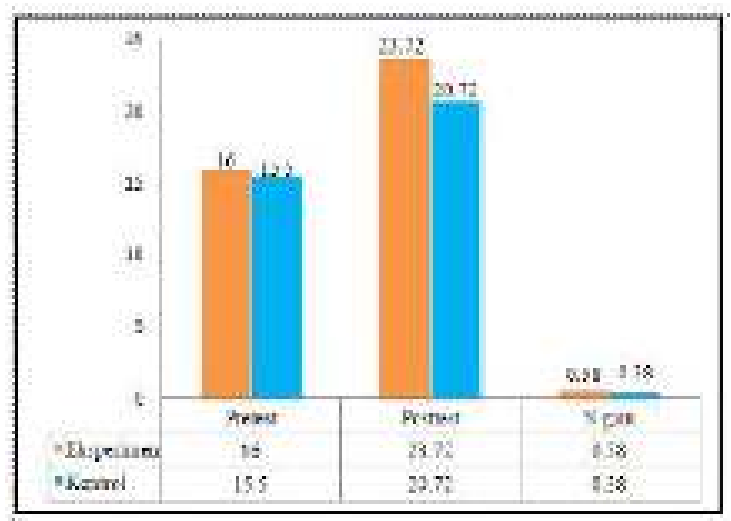

Gambar 1. Diagram Batang Perbandingan

Rata-rata Skor Pretest, Posttest, dan N-gain

Hasil Belajar Peserta Didik di Kelas

Eksperimen dan Kelas Kontrol

Berdasarkan gambar 1 menunjukkan perbedaan skor rata-rata pretest, posttest, $\mathrm{N}$ gain kelas eksperimen dan kelas kontrol didapatkan bahwa rata-rata skor pretest, posttest, dan $\mathrm{N}$-gain hasil belajar peserta didik di kelas eksperimen yang pembelajarannya dibantu dengan menggunakan media peta konsep lebih tinggi dibandingkan dengan kelas kontrol. Skor rata-rata $\mathrm{N}$-gain yang diperoleh di kelas eksperimen yaitu 0,58 sedangkan skor rata-rata $\mathrm{N}$-gain hasil belajar peserta didik di kelas kontrol yaitu 0.38 . Nilai $\mathrm{N}$-gain di kelas eksperimen lebih tinggi dibandingkan dengan kelas kontrol. Hal tersebut disebabkan karena penggunaan media peta konsep mengakibatkan peserta didik mampu lebih aktif dalam proses pembelajaran berlangsung.

Hasil penelitian yang dilakukan oleh Yunita, Luki.,et.all (2014:6-8) menyatakan bahwa,"Pembuatan peta konsep mengakibatkan peserta didik siap untuk belajar dan aktif dalam proses pembelajaran. Oleh karena itu, hasil belajar yang didapatkan di kelas eksperimen mengalami peningkatan daripada kelas kontrol tanpa menggunakan peta konsep". Penelitian yang dilakukan oleh Labibah, Raisyah $\mathrm{M}$ dan Irnawati, Tias (2017) menyatakan bahwa "kecenderungan hasil belajar IPA yang pembelajarannya menggunakan peta konsep termasuk sangat tinggi. Hal ini disebabkan karena penggunaan peta konsep ini dapat meningkatkan keaktifan siswa dalam proses 
belajar. Penggunaan peta konsep ini dapat meningkatkan pemahaman siswa karena peta konsep merupakan cara belajar yang mengembangkan proses belajar bermakna, sebagai sarana untuk membiasakan otak berfikir terkonsep dalam segala hal".

Untuk melihat perbandingan skor hasil belajar pada dimensi proses kognitif peserta didik di kelas eksperimen dan kelas kontrol dapat dilihat pada gambar 2 berikut ini;

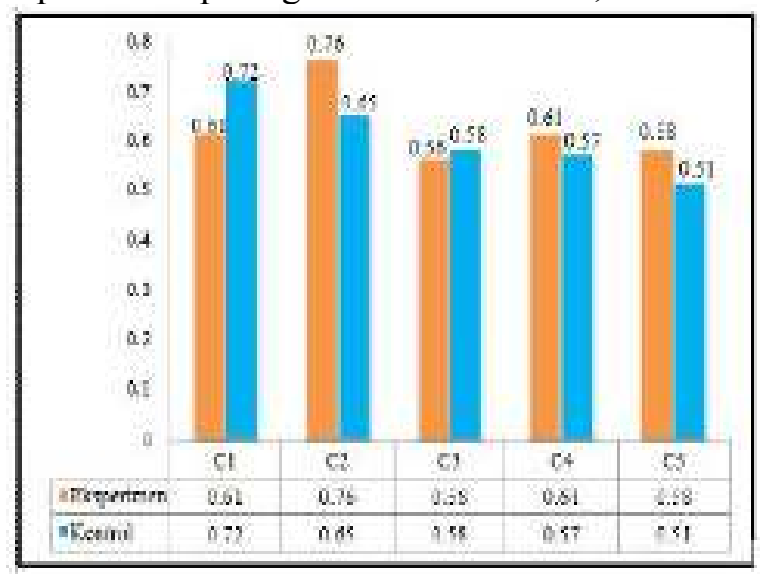

Gambar 2. Diagram Batang Perbandingan

Skor Hasil Belajar pada Dimensi Proses

Kognitif Peserta Didik di Kelas Eksperimen dan Kelas Kontrol

Berdasarkan gambar 2 dapat disimpulkan bahwa hasil belajar pada dimensi proses kognitif dikelas kontrol yang berkembang pada indikator mengetahui (C1) sedangkan hasil belajar dimensi proses kognitif yang berkembang di kelas eksperimen pada indikator memahami (C2). Untuk perbandingan skor hasil belajar pada dimensi pengetahuan kognitif di kelas eksperimen dan kelas kontrol sebagai berikut:

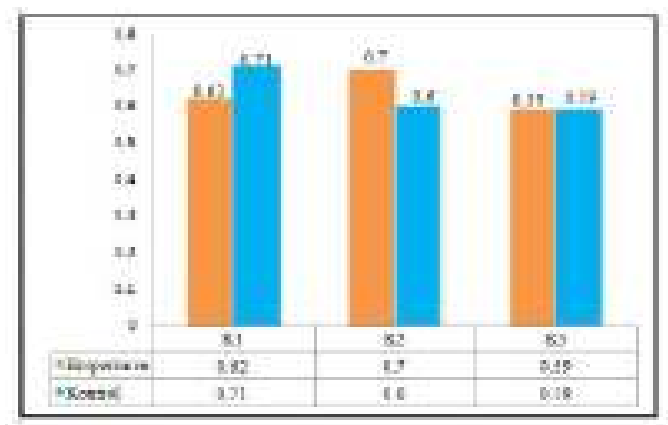

Gambar 3. Diagram Batang Perbandingan Skor Hasil Belajar pada Dimensi Pengetahuan Kognitif Hasil Belajar Peserta Didik di Kelas Eksperimen dan Kelas Kontrol
Berdasarkan gambar 3 dapat disimpulkan bahwa hasil belajar pada dimensi pengetahuan kognitif dikelas kontrol yang berkembang pada pengetahuan faktual (K1) sedangkan hasil belajar dimensi pengetahuan kognitif yang berkembang di kelas eksperimen yaitu pengetahuan konseptual (K2).

Media peta konsep dapat mengembangkan hasil belajar pada dimensi proses kognitif pada ranah $\mathrm{C} 2$ (memahami) dan dimensi pengetahuan kognitif pada ranah K2 (pengetahuan konseptual). Karena dengan media peta konsep membuat peserta didik dapat membangun pengetahuannya sendiri menemukan konsep-konsep mengenai sistem indera. Hal tersebut sejalan dengan Lestari,S (2016:156) menyatakan bahwa. "Penggunaan peta konsep dapat meningkatkan pemahaman terhadap konsep-konsep yang sedang dipelajari, karena peserta didik dapat belajar secara mandiri dan mengembangkan stuktur kognitif yang terintegrasi dengan baik".

Hasil Penelitian yang dilakukan oleh Roini, Chumaidah (2012:29) juga menemukan bahwa, "Penerapan peta konsep pada pembelajaran meningkatkan pemahaman peserta didik terhadap konsep genetika, sehingga hasil belajar yang didapatkan juga mengalami peningkatan". Adapun menurut Musyrifah dan Ismail (2014:12) menyatakan bahwa, "Peta konsep merupakan representasi dari beberapa konsep yang dapat meningkatkan semangat belajar peserta didik dan lebih aktif dalam membangun pengetahuan secara mandiri sehingga dapat meningkatkan penguasaan konsep-konsep dari suatu materi yang dipelajari”.

Adapun peta konsep sistem indera yang telah dibuat oleh peserta didik sebagai berikut;

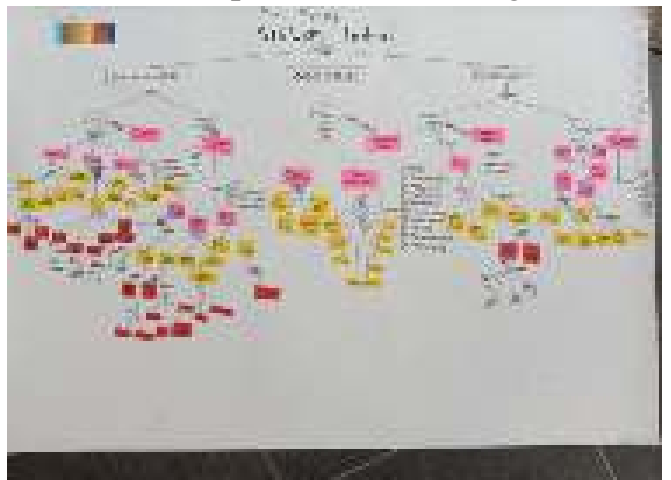

Gambar 4. Peta Konsep Sistem Indera Peserta Didik 
Gambar 4 menunjukkan peta konsep sistem indera yang telah dibuat oleh peserta didik. Peta konsep tersebut terdiri dari beberapa bagian yaitu hierarki yang diberi tanda dengan warna, proposisi yaitu dua konsep yang dihubungkan dengan kata penghubung, kaitan silang dan contoh.

Adapun pada proses pembelajaran dengan menggunakan peta konsep terdapat beberapa kendala, yaitu peserta didik mengalami kesulitan dalam membuat peta konsep khususnya pada bagian mengurutkan konsep dari konsep konsep umum ke konsep khusus, hal itu dikarenakan mereka belum terbiasa dalam membuat peta konsep serta proses pembelajaran dilaksanakan secara daring, sehingga mengakibatkan peserta didik belum terlalu paham dan mengalami kesulitan dalam membuat peta peta konsep. Oleh karena itu, skor hasil belajar pada dimensi proses kognitif dan pengetahuan kognitif di kelas eksperimen belum maksimal, maka dari itu diperlukan pembiasaan peta konsep lebih intens lagi kepada peserta didik.

Hal tersebut sejalan dengan Musyrifah dan Ismail (2014:12) yang menyatakan bahwa "peta konsep dapat lebih meningkatkan hasil belajar siswa jika digunakan secara berulang-ulang dalam proses belajar. Selain itu, dibutuhkan pula masa pelatihan dan umpan balik secara langsung dengan waktu yang cukup lama untuk memberikan kesempatan kepada siswa dalam menguasai secara lebih detail cara membuat peta konsep".

Penelitian yang dilakukan oleh Labibah, Raisyah $M$ dan Irnawati, Tias (2017) menjelaskan

\section{SIMPULAN}

Berdasarkan hasil penelitian dapat disimpulkan bahwa terdapat perbedaan skor Ngain kelas eksperimen dan kelas kontrol, dimana skor N-gain kelas eksperimen lebih besar dibandingkan dengan kelas kontrol oleh karena itu media peta konsep berpengaruh terhadap hasil belajar peserta didik pada sub konsep sistem indera di Kelas XI IPA di salah satu sekolah menengah atas di Tasikmalaya. Pada kelas eksperimen hasil belajar dimensi proses kognitif yang paling tinggi pada ranah memahami (C2) sedangkan pada dimensi pengetahuan kognitif yang paling tinggi yaitu pengetahuan konseptual (K2). Pada kelas kontrol hasil belajar dimensi proses kognitif yang paling tinggi pada ranah mengingat $(\mathrm{C} 1)$ sedangkan pada dimensi pengetahuan kognitif yang paling tinggi yaitu pengetahuan faktual (K1).

\section{UCAPAN TERIMA KASIH}

Ucapan terimakasih penulis sampaikan kepada pembimbing yang telah memberi arahan dalam pembuatan artikel ini, dan kepada pihak sekolah yang telah memberikan izin dan kesempatan untuk melaksanakan penelitian ini. Serta kepada para siswa yang telah terlibat sebagai subjek dalam penelitian ini.

\section{REFERENSI}

Arsyad, Azhar. (2010). Media pembelajaran.Jakarta:PT Rajagrafindo Persada.

Dahar, Ratna Wilis. (2006). Teori-teori belajar dan pembelajaran. Erlangga:PT Bumi Aksara Pratama.

Labibah, Raisah Mardhiyati. (2017). Pengaruh penggunaan peta konsep terhadap hasil belajar ipa ditinjau dari kemampuan berpikir kritis. Jurnal Ilmiah Pendidikan Ipa 4(2).

Lestari, S., et.all. (2016). Hubungan Kemampuan Membuat Peta Konsep Dengan Hasil Beljar Siswa Pada Sub Materi Klasifikasi Mahluk Hidup Kelas X SMA Esa Prkarsa. Jurnal Pelita Pendidikan 4(4):156-160.

Marisa. (2016). Modul konsep pemanfaatan media dalam pembelajaran. [E-Book] tersedia

http://www.academia.edu/37540562/kon sep_pemanfaatan_media_dalam_pembel ajaran.

Meltzer, David E. (2002). The relationship between mathematichs preparation and conceptual learning gains in physics: A possible hidden variable in diagnostic pretest score. Journal American Association of physics teachers, 70 (12):1259-1268. 
Musyrifah dan Ismail. (2014). Pengaruh penerapan peta konsep berbasis it terhadap hasil belajar kognitif biologi siswa kelas XI IPA SMAN 1 pambong pada materi sel. Jurnal Bionature, 15(1):6-15.

Novak, Joseph D dan Gowin, D Bob.(1984). Learning how to learn. [E-Book] tersedia di https://www.ebooks.com/enus/book/1217999/learning-how-tolearn/joseph-d-novak/..

Roini, Chumaidach. (2012). Peningkatan Pemahaman Konsep Genetika Siswa SMA Melalui Pembelajaran Peta Konsep Pada Sekolah Berkategori Berbeda. Jurnal Bionature 13(1):25-30.

Sugiyono. (2017). Metode penelitian kebijakan. Bandung:Alfabeta.

Vanides, Jim. (2005). Using Concept Maps in the Science Classroom. Jurnal National Science Teacher Association (NSTA), 28 (8).

Yunita, Luki., et.all. (2014). Pemanfaatan Peta Konsep Untuk Meningkatkan Pemahaman Siswa Tentang Konsep Senyawa Hidrokarbon. Jurnal Edusains, (1):1-18. 